\title{
Temporal and spatial patterns of settlement of brachyuran crab megalopae at a rocky coast in Central Portugal
}

\author{
Augusto A. V. Flores*, Joana Cruz, José Paula \\ Instituto do Mar, Laboratório Marítimo da Guia, Faculdade de Ciências da Universidade de Lisboa, Estrada do Guincho, \\ 2750-642 Cascais, Portugal
}

\begin{abstract}
Square mesh traps placed under natural boulder cover were used to obtain in situ settlement rates of intertidal brachyurans along a rocky coast within the Cascais area, Central Portugal. Megalopae of all intertidal species known to occur in this region were present in the samples. The settlement variability within different spatial scales, i.e. hundreds, tens and unit metres, were tested for the most abundant species, Pachygrapsus marmoratus, using a nested analysis of variance design. A significant contrast was found between areas $1.5 \mathrm{~km}$ apart, while no differences were detected at lower spatial scales. Spatial heterogeneity is likely to depend on coastal hydrological patterns rather than smaller-scale processes such as substrate selection. Fine time series settlement data were obtained for $P$. marmoratus and Xantho incisus, which were analysed for periodic patterns and correspondence to tide range and wind speed components. Across-shore wind forcing was found to be the major factor affecting settlement for both species, although in inverse ways. While onshore winds favour settlement of $P$. marmoratus, it is the relaxation of the onshore component or contrary offshore forcing that is apparently transporting the megalopae of $X$. incisus ashore. We predict that the vertical distributions of $X$. incisus and $P$. marmoratus megalopae are different within the inner shelf and that wind-driven upwelling and downwelling compensating coastal flows are largely determining their temporal abundance variation. In the case of $P$. marmoratus, there is also a secondary but significant effect of tides on the abundance of megalopae. An increasing number of settlers on traps was verified during periods of higher tide range. This seems to be particularly marked during spring tides around the new moon, but there is no statistical support for such a trend.
\end{abstract}

KEY WORDS: Settlement patterns - Rocky intertidal zone - Brachyuran crabs · Megalopae · Log-linear models

Resale or republication not permitted without written consent of the publisher

\section{INTRODUCTION}

Settlement and subsequent recruitment to the adult population are major processes influencing population dynamics of marine invertebrates with meroplanktonic development. At benthic population densities below the carrying capacity of a given system, the supply of new settlers to the adult habitat may condition species abundance (Gaines \& Roughgarden 1985, Roughgar-

\footnotetext{
*E-mail: aflores@fc.ul.pt
}

den et al. 1988). Nearby areas under the influence of divergent hydrological conditions may hold contrasting densities of recent recruits of the American lobster because of differential availability of planktonic postlarvae (Wahle \& Incze 1997). In fact, the commercial catch of rock lobsters and Dungeness crabs can be anticipated 4 to $5 \mathrm{yr}$ ahead due to significant relationships between post-larval supply and commercial landings (Johnson et al. 1986, Phillips 1986).

Causes of temporal variation of settlement rate are usually indicated by means of testing the significance of relationships between long time series records of settle- 
ment rates and hypothesised influencing factors. Results obtained in many such studies suggest that complex processes involving different variables could be responsible for the patterns observed. For instance, settlement of the blue crab Callinectes sapidus in Chesapeake Bay is known to depend on southward wind drift over the shelf, which retrieves larvae previously advected to the north and favours their transport into the estuary (Goodrich et al. 1989, Johnson \& Hester 1989, Johnson \& Hess 1990, Jones \& Epifanio 1995). Yet studies using passive collectors deployed inside the Chesapeake estuarine system have also found the effect of lunar phase, indicating either higher settlement during periods of higher tide amplitude corresponding to the full moon (van Montfrans et al. 1990) and new moon (Mense et al. 1995) or lower tide range during the waning moon (Boylan \& Wenner 1993). Semilunar periodicity was also found by Metcalf et al. (1995) but interannual variation prevented definition of a regular pattern. Mense et al. (1995) suggested that larval flux in smaller estuaries might be mainly influenced by tidally driven mechanisms, while wind-induced drift would be the most important factor in larger systems. Since within-marsh settlement necessarily depends on events taking place while larvae are in offshore and estuarine waters, complex and often contrasting patterns such as those cited above would be a result of factors operating during both phases. Therefore, data obtained on estuarine settlement cannot be used to unambiguously examine cross-shelf transport (Shanks 1998). Information on the settlement patterns of coastal intertidal crabs would contribute to the identification of the mechanisms involved in this process.

Apart from the research carried out on the Californian shore crab Pachygrapsus crassipes there have been no attempts to obtain settlement records at fine temporal scales for any marine intertidal brachyuran. As in other crabs inhabiting intertidal rocky shores, the megalopae of $P$. crassipes must reach and settle on a narrow rocky belt often exposed to considerable wave action. The actual process of settlement in the intertidal environment is still unknown, but daily collections of megalopae at a seaward site located $320 \mathrm{~m}$ from the shore revealed a remarkable fortnightly cycle with peak catches regularly just preceding spring tides (Shanks 1983). The author suggested that these larvae are probably transported onshore by unbroken internal waves originated at the shelf break during tides of lower amplitude. The megalopa of this species can be effectively transported due to its characteristic behavioural response to physical stimuli (Shanks 1985) and swimming capabilities (Shanks 1995a).

Brachyuran crabs are usually abundant inhabitants of the intertidal zone of rocky shores from warm temperate to tropical latitudes. Their important role in the community dynamics may be predicted but experimental evidence of such a role has been seldom tested. Benthic crab populations in rocky shores are relatively well studied, including growth of discrete age groups (McDonald 1982, Fukui 1988, Tsuchida \& Watanabe 1997), population structure (e.g. Swartz 1976, Vannini \& Gherardi 1988, Yau 1992, Flores \& NegreirosFransozo 1999) and breeding (e.g. Broekhuysen 1941, Knudsen 1960, Fukui 1990, Flores \& NegreirosFransozo 1998). In contrast, there is a virtual lack of information concerning their larval ecology. In this study we measured settlement rates of intertidal brachyurans in natural cobble areas enclosed in major bedrock shores. Settlement variability within different spatial scales was compared for the most abundant species to provide a basis for sampling replication and to obtain preliminary clues on the nature of mechanisms promoting settlement. To judge the likelihood of potential mechanisms assisting cross-shelf transport at the study area, we sampled for the occurrence of megalopae over 2 settlement seasons and evaluated the influence of wind components, tide range and lunar phase as factors explaining the patterns obtained.

\section{MATERIALS AND METHODS}

Collection and identification of megalopae. In a first attempt to obtain settlement estimates, the commonly used 'hogshair' air conditioning filter material (e.g. O'Connor 1993, Rabalais et al. 1995, Paula et al. 2001) was used as settling surfaces coating PVC pipe sections fixed on the rock surface. As verified for megalopae settling in coral reefs (Reyns \& Sponaugle 1999), this sort of material proved to be inefficient. A modified trap for collecting porcelain crabs (Oliveira et al. 1995) rendered much better results. Square mesh pieces $(0.5 \times 0.5 \mathrm{~m}, 1 \mathrm{~mm}$ mesh size $)$ were placed under natural cobble cover, approximately $40 \mathrm{~cm}$ below the surface. Every other day, the cobble at the sampling plots was removed and washed in a large plastic basin, together with the mesh trap itself. The water inside the basin was then passed through a $1 \mathrm{~mm}$ sieve, and all the obtained material was placed inside a vial by rinsing the sieve into a funnel. Upon arrival at the laboratory, the vial contents were emptied over a white plastic tray covered with freshwater. All debris to which megalopae could possibly cling to, mostly detached algae, was vigorously shaken and discarded. Once cleaned, the tray was screened under magnification to separate megalopae.

All individuals but a single pinnotherid specimen were identified to species. Their identification was possible with the descriptions provided by Lumare \& Gozzo (1972), Rice \& Ingle (1975), Ingle (1991), Guerao 
et al. (1997) and Flores \& Paula (2000). Microscopic observation was only required to separate the megalopae of Carcinus maenas, Pirimela denticulata and Necora puber. The number of individuals collected of each species and sample was recorded.

Spatial patterns. Tested spatial scales of settlement variability were hundreds, tens and unit metres. Two different areas $1.5 \mathrm{~km}$ apart, i.e. Cabo Raso and Raio Verde, were chosen for sampling due to the availability of suitable areas with cobble coverage (Fig. 1). Within each area, 2 sites 100 to $170 \mathrm{~m}$ apart were delimited, in which 3 sampling plots separated by 6 to $10 \mathrm{~m}$ were set. All plots were located in the lower intertidal zone ranging between 1.0 and $1.3 \mathrm{~m}$ above chart datum. A nested ANOVA (Underwood 1997) was chosen to compare the settlement variability between the 'area', 'site' and 'plot' levels, using samples taken throughout the 1999 recruitment season as replicates ( $\mathrm{n}=16$ sampling dates in which all plots could be simultaneously sampled). To achieve homogeneity of variances data were transformed to $\sqrt{(x+1)}$. For species occurring at low numbers preventing detailed analysis, a $G$-test of goodness of fit corrected according to Williams (1976) was used to test abundance differences between sampled areas.

Temporal patterns. Samples were taken during 2 different seasons to assess interannual variability of settlement. The first was from 31 August to 1 December 1999 and the second from 3 June to 30 October 2000. All areas (Fig. 1) were sampled during the first study period, but because of natural disturbance of area 1 and logistic constraints, only areas 2, 3 and 4 could be sampled in the second period. Within each sampling season, time series settlement data were preliminary tested for fortnightly and lunar cycles. For that, data were subjected to spectral analyses and periodograms were obtained (Rayner 1971). To test whether time series data differed from a 'white noise' series, the distribution of periodogram values was tested against the exponential distribution using a Kolmogorov-Smirnov (K-S) 1 sample test (Rohlf \& Sokal 1981, Sokal \& Rohlf 1995). When significant semilunar periodicity was detected, the cross-correlation between settlement rate and tide range was determined to estimate the phase shift between the 2 variables. Tide values corresponded to daily averages obtained from published tables for the Cascais harbour, nearly $5 \mathrm{~km}$ distant from the study area. Apart from tide range, wind was also regarded as a possible factor influencing temporal patterns of settlement variation. Average wind speed and direction were calculated from 2 daily readings provided by the Cabo da Roca station (9 $\mathrm{km}$ north of Cabo Raso) of the Instituto de Meteorologia. Wind speeds were decomposed into their along- and across-shore components as per-

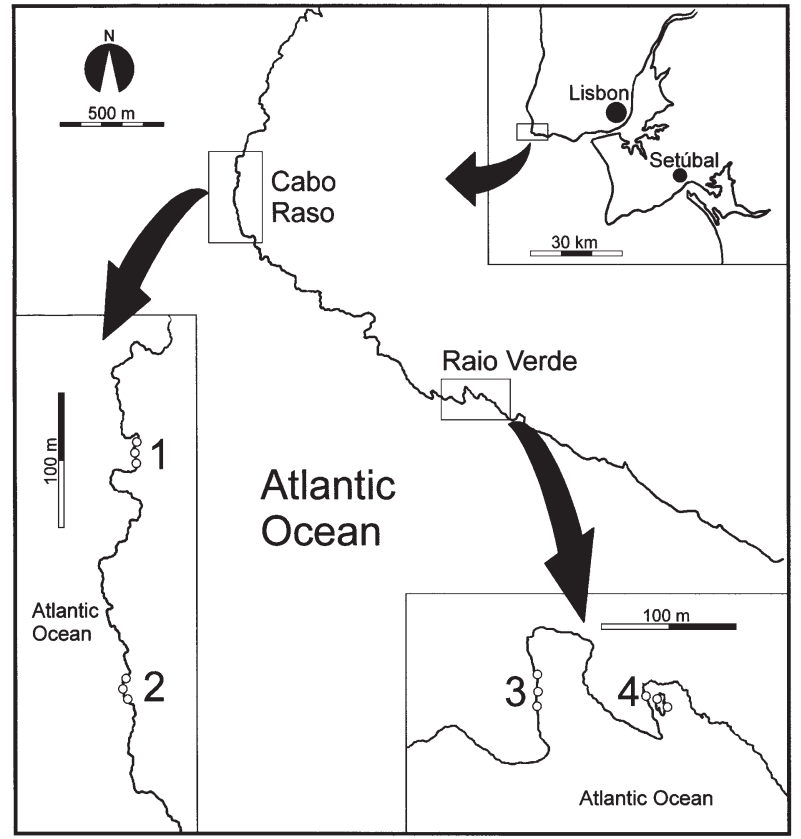

Fig. 1. Map of the sampling areas Cabo Raso and Raio Verde, showing the detailed location of study sites (1 to 4) and approximate position of sampling plots

formed by Jones \& Epifanio (1995). In our study, we set the along- and across-shore directions to the northsouth and west-east axes, respectively, considering the geographic orientation of the Portuguese coast.

Log-linear models (Bishop et al. 1975, Sokal \& Rohlf 1995) were used to assess the relative importance of tide range and wind speed as factors influencing settlement rate. Three-way contingency tables also allow testing of the interaction between these factors. Separate models were fitted to each species, year, wind component and number of preceding days, up to 8 , accounting for the cumulative effect of wind. This statistical procedure requires data to be initially categorised in a suitable number of intervals to avoid null frequencies. In all cases, variables were split into categories of equal or subequal number of observations: 2 in the case of tide range and wind speed, and 2 or 3 for settlement rate. Separating those variables into more categories would not improve the testing of the general models proposed in this study. When significant 2 -factor interactions were found, i.e. 'settlement $x$ tide range' or 'settlement $x$ wind speed', the initial test was decomposed to verify which were the contrasting factor levels in the case when 3 settlement categories were used. Otherwise, examining the sign of deviations against expected values was sufficient to assess how variables are related. When significant 3 -factor interactions were detected, i.e. 'settlement $\times$ tide range 
Table 1. Overall species composition and temporal distribution of sampled megalopae. Settlement periods represent broadest intervals from the combined data of both sampling periods. Cm: Carcinus maenas; Ev: Eriphia verrucosa; Pd: Pirimela denticu-

lata; Np: Necora puber; Ph: Pilumnus hirtellus; Pm: Pachygrapsus marmoratus; Psp: Pinnotheres sp.; Xi: Xantho incisus

\begin{tabular}{|c|c|c|c|c|c|c|c|c|c|c|c|}
\hline \multirow[t]{3}{*}{ Species } & \multicolumn{4}{|c|}{ Year (sampling period: dd/mm) } & \multicolumn{2}{|c|}{ Total } & \multicolumn{5}{|c|}{ Temporal distribution } \\
\hline & \multicolumn{2}{|c|}{1999 (31/08 to 03/12) } & \multicolumn{2}{|c|}{$2000(03 / 06$ to $30 / 10)$} & \multirow[b]{2}{*}{$\mathrm{n}$} & \multirow[b]{2}{*}{$\%$} & \multirow[t]{2}{*}{ Jun } & \multirow[t]{2}{*}{ Aug } & \multirow[t]{2}{*}{ Sep } & \multirow[t]{2}{*}{ Oct } & \multirow[t]{2}{*}{ Nov } \\
\hline & $\mathrm{n}$ & $\%$ & $\mathrm{n}$ & $\%$ & & & & & & & \\
\hline $\mathrm{Pm}$ & 79 & 89.77 & 1472 & 89.05 & 1551 & 89.09 & & $\mathrm{xxxxx}$ & $\operatorname{xxxxx}$ & $\operatorname{xxxxxx}$ & \\
\hline $\mathrm{Xi}$ & 6 & 6.82 & 156 & 9.44 & 162 & 9.30 & & $\operatorname{xxxxxx}$ & xxxxx & $\operatorname{xxxx}$ & \\
\hline $\mathrm{Np}$ & 2 & 2.27 & 10 & 0.61 & 12 & 0.69 & $\operatorname{xxxxxxxxxx}$ & $\operatorname{xxxxxx}$ & $\mathrm{xxxx}$ & & \\
\hline $\mathrm{Pd}$ & - & - & 6 & 0.36 & 6 & 0.34 & $\mathrm{xxxxx}$ & & & & \\
\hline Ev & 1 & 1.14 & 3 & 0.18 & 4 & 0.23 & & $\mathrm{xxxxx}$ & $\mathrm{xxxxx}$ & & \\
\hline $\mathrm{Ph}$ & - & - & 4 & 0.24 & 4 & 0.23 & $\mathrm{xxxxx}$ & & & & \\
\hline $\mathrm{Cm}$ & - & - & 1 & 0.06 & 1 & 0.06 & & $\mathrm{x}$ & & & \\
\hline Psp & - & - & 1 & 0.06 & 1 & 0.06 & & & $\mathrm{x}$ & & \\
\hline Total & 88 & & 1653 & & 1741 & & & & & & \\
\hline
\end{tabular}

$\times$ wind speed', the test was decomposed into separate 2 -way contingency tables as settlement $\times$ wind speed in each tide range category or settlement $\times$ tide range in each wind speed category.

\section{RESULTS}

Overall numbers of megalopae collected over the study period are shown in Table 1. The grapsid Pachygrapsus marmoratus was by far the most abundant species, comprising almost $90 \%$ of all individuals, followed by Xantho incisus, which was relatively common in samples. The remaining species may be considered occasional. Species abundance rankings appear to vary little between sampled periods, but detailed comparisons were precluded due to the small number of megalopae obtained in 1999. Considering the same sampled areas and the intersecting periods of known settlement occurrence during the 2 sampled seasons, the abundance of settling megalopae in 2000 is estimated to have been 9- and 14-fold higher for $X$. incisus and $P$. marmoratus, respectively. The temporal distribution of the studied species roughly indicates 2 groups: a first group of early settlers including Necora puber, Pirimela denticulata and Pilumnus hirtellus and a sec-

Table 2. Nested analysis of variance of spatial variability in settlement rate for Pachygrapsus marmoratus during the 1999 sampling period

\begin{tabular}{|lrcrc|}
\hline Source of variation & df & ms & Fratio & p-value \\
\hline Area & 1 & 0.692 & 27.01 & 0.04 \\
Site (area) & 2 & 0.026 & 0.69 & 0.53 \\
Plot (site(area)) & 3 & 0.037 & 0.80 & 0.61 \\
Residual & 180 & 0.047 & & \\
Total & 191 & & & \\
\hline
\end{tabular}

ond group of later settlers consisting of the species $P$. marmoratus, $X$. incisus and Eriphia verrucosa.

\section{Spatial patterns}

Because of the low settlement rates observed in 1999, estimating the spatial scales of settlement variability was only possible for the most abundant species, Pachygrapsus marmoratus. Sampling dates accounting for this analysis were scattered along the study period when all plots could be recovered. Areas of natural cobble deposition are usually less exposed, but upper layers may eventually roll and dislodge the traps when large waves are formed.

Table 2 shows the results of the hierarchical ANOVA to assess spatial variability of settlement. Variation at the 'plot' and 'site' levels was not significant. Settlement rates were only different at the 'area' level, corresponding to locations separated by $1500 \mathrm{~m}$. Settling megalopae of Pachygrapsus marmoratus were more

Table 3. Comparison of each species' abundance between sampled areas. Expected values are calculated according to the number of valid records for each area. Abbreviations as in Table 1. Bold denotes statistical significance at $p<0.001$

\begin{tabular}{|c|c|c|c|c|c|}
\hline \multirow[t]{3}{*}{ Species } & \multicolumn{4}{|c|}{ No. of megalopae } & \multirow[t]{3}{*}{$G_{\text {adj }}$} \\
\hline & \multicolumn{2}{|c|}{ Cabo Raso } & \multicolumn{2}{|c|}{ Raio Verde } & \\
\hline & Obs. & Exp. & Obs. & Exp. & \\
\hline $\mathrm{Pm}$ & 253 & 564.6 & 1298 & 986.4 & 306.3 \\
\hline $\mathrm{Xi}$ & 131 & 59.0 & 31 & 103.0 & 134.2 \\
\hline $\mathrm{Np}$ & 11 & 4.4 & 1 & 7.6 & 15.6 \\
\hline $\mathrm{Pd}$ & 6 & 2.2 & 0 & 3.8 & - \\
\hline Ev & 2 & 1.5 & 2 & 2.5 & - \\
\hline $\mathrm{Ph}$ & 2 & 1.5 & 2 & 2.5 & - \\
\hline $\mathrm{Cm}$ & 1 & 0.4 & 0 & 0.6 & - \\
\hline Psp & 0 & 0.4 & 1 & 0.6 & - \\
\hline
\end{tabular}


abundant at Raio Verde than at Cabo Raso. Although settlement variation was not examined in such detail, there is evidence that at the 'area' level it is also occurring in other species (Table 3). Yet it is interesting to note that significant differences between Xantho incisus and Necora puber indicate higher abundance of settlers at Cabo Raso instead. For the remaining species, adequate tests could not be performed due to low numbers of observations, but numerical differences also suggest a higher settlement of Pirimela denticulata at Cabo Raso.

\section{Temporal patterns}

A closer study of temporal settlement patterns was only possible for the dominant species, Pachygrapsus marmoratus (for both 1999 and 2000 sampling periods) and Xantho incisus (only for 2000). In 1999, analyses included all data since the sampling period was well within the known settlement season of $P$. marmoratus. In 2000, early null records were excluded because prior sampling from early June allowed us to assume that settlement still had not begun at that time. Because of the heterogeneous distribution over the study zone, only traps set at Site 2 and Raio Verde were sampled for $X$. incisus and $P$. marmoratus, respectively, during the 2000 sampling period.

Settlement rates as indicated by number of megalopae per trap are shown for Pachygrapsus marmoratus (Figs. 2 \& 3) and Xantho incisus (Fig. 3). A lunar cycle centred on the new moon is apparent for P. marmoratus in 1999 (Fig. 2), which is confirmed by the corresponding periodogram in which a discrete peak at a frequency relative to a period of $30 \mathrm{~d}$ is evident and significant (Fig. 4; K-S test: $\mathrm{d}=0.57, \mathrm{p}<0.01$ ). In 2000 , the temporal distribution of $P$. marmoratus megalopae peaked conspicuously around the new moon of August 29 , but adjacent peaks approximately around the full moon suggested a semilunar cycle. When the data were analysed for the whole frequency range, the periodogram showed a major peak corresponding to a period of $84 \mathrm{~d}$ (K-S test: $\mathrm{d}=0.62, \mathrm{p}<0.01$ ), probably due to the masking effect of the major settlement peak. After defining a frequency subset including the most likely working cycles, i.e. periods ranging from 4 to $35 \mathrm{~d}$, the highest peak corresponded to a period of $14 \mathrm{~d}$ (Fig. 4 ; K-S test: $\mathrm{d}=0.58, \mathrm{p}<0.01$ ), very close to the semilunar period. For $X$. incisus, no further sampling was conducted after September 28, due to persistent disturbance on the cobble area at site 2 from September 29 to October 4 . The record permits the identification of discrete peaks, but no periodicity is apparent by visual inspection of the plot presented in Fig. 3. Spectral analysis rendered a periodogram indicating a sig-

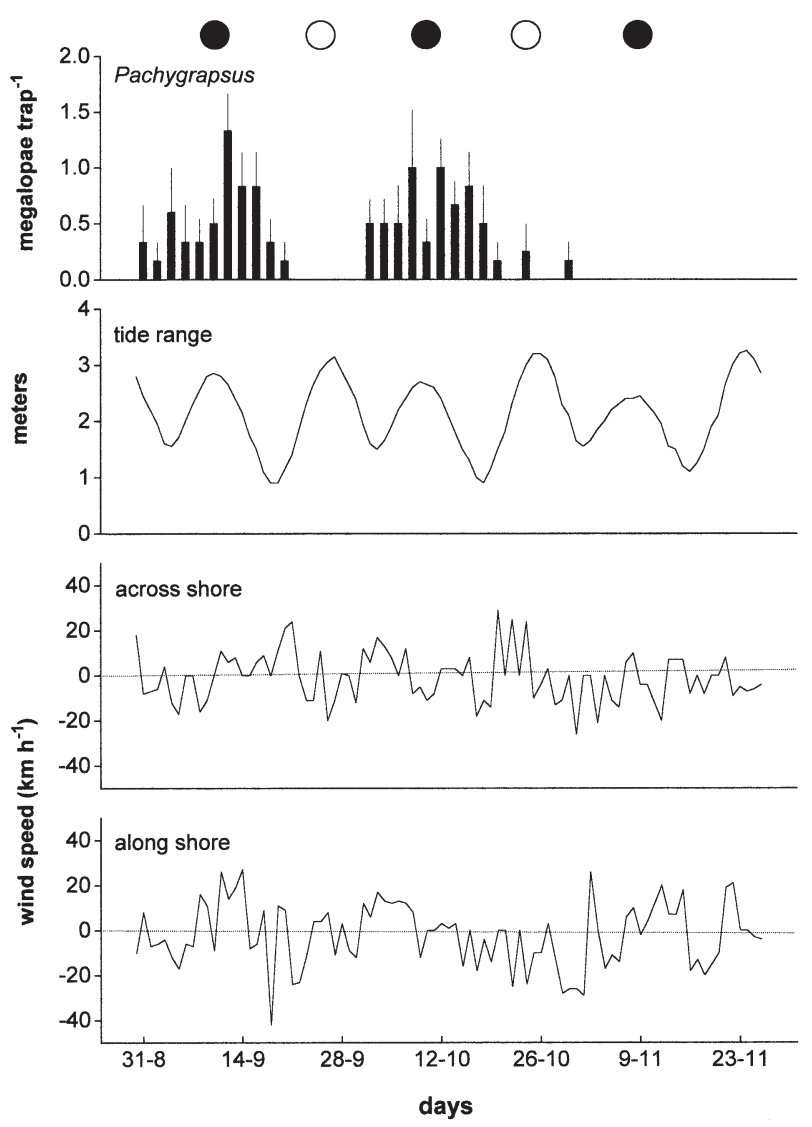

Fig. 2. Pachygrapsus marmoratus. Time series data for the 1999 sampling period. In the settlement series, columns indicate average values and bars $\pm 1 \mathrm{SE}$. Positive values in wind data indicate eastward and southward directions for acrossand along-shore components, respectively

nificant period of $64 \mathrm{~d}$ (K-S test: $\mathrm{d}=0.35, \mathrm{p}<0.01$ ), again interpreted as a result of the single major settlement peak on August 29. Testing for significant peaks within pertinent ranges indicated a significant period of $12.8 \mathrm{~d}$ (Fig. 4 ; K-S test: $\mathrm{d}=0.32, \mathrm{p}<0.01$ ).

Cross-correlations were run between settlement rate and tide range to verify whether semilunar periods suggested by spectral analysis for the 2000 settlement series find independent support. A negative significant correlation was detected for Pachygrapsus marmoratus with a lag of $-6 \mathrm{~d}$ (Fig. 5). Although a positive correlation near lag 0 was not detected, this result supports a semilunar cycle in pace with tidal variation. Synchronic variation between tides and settlement would also be supported by negative significant correlations at lags of $\pm 7 \mathrm{~d}$. A negative correlation at $-6 \mathrm{~d}$ does not suggest a significant phase deviation, since temporal sampling was undertaken at a precision of $\pm 2 \mathrm{~d}$. In the case of Xantho incisus, no significant correlations were found. 

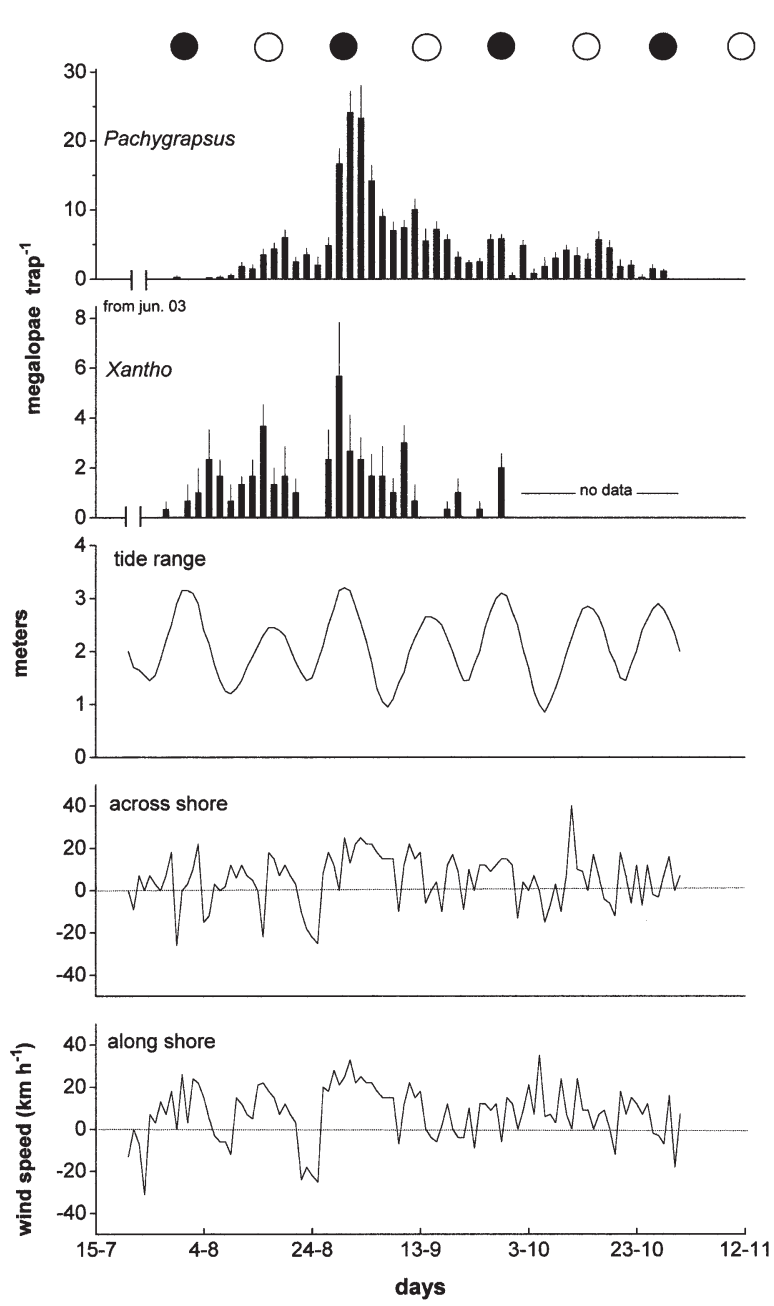

Fig. 3. Pachygrapsus marmoratus and Xantho incisus. Time series data for the 2000 sampling period. Details as in Fig. 2 noted that separating wind data in 2 equally sized categories did not imply a division of data into negative and positive values. During the 2000 sampling period, positive onshore wind components prevailed (Fig. 3), so that high settlement of $X$. incisus occurs mostly when both offshore and relaxation of onshore components take place. The picture for Pachygrapsus marmoratus is quite contrasting. Onshore winds were found to be associated with higher settlement during both sampling periods (Tables $5 \& 6$, Fig. 7). This trend was significant in the 1999 season when the cumulative effect of winds from 2 and 5 preceding days was accounted for and during 2000 when 2 and 6 to 8 days were considered. Yet the effect of onshore winds may be cancelled under conditions of high tide range (Table 6, Fig. 7). In this species, along-shore northerly wind components and high tide ranges may also be related to high settlement (Table 6).

The effect of lunar phase is difficult to assess because settlement peaks are protracted over long periods, in the order of 10 to $12 \mathrm{~d}$ (Fig. 3). Goodness-of-fit procedures are therefore hard to apply because the number of peaks attributable to each lunar phase is insufficient for conducting the tests. Higher settlement rates around new moon periods, especially in the case of Pachygrapsus marmoratus, appear too frequent to be distributed by chance, but additional data are required to test this hypothesis.

\section{DISCUSSION}

In the present study we used mesh traps to collect megalopae in a natural settlement microhabitat along a
Because winds from the north-west prevailed during the 2000 sampling period, the variation of along- and across-shore wind components was relatively similar (Fig. 3). However, loglinear models fitted to time series data showed that the across-shore wind speed component was the most important factor affecting settlement rate in both species (Tables 4 to 6). There was no apparent effect of tides or alongshore wind components on the settlement rate of Xantho incisus (Table 3). In this species, across-shore winds began to exert their influence after 3 preceding days. In all cases, higher settlement rates corresponded to negative or low onshore wind speed components, as shown in Fig. 6. It should be

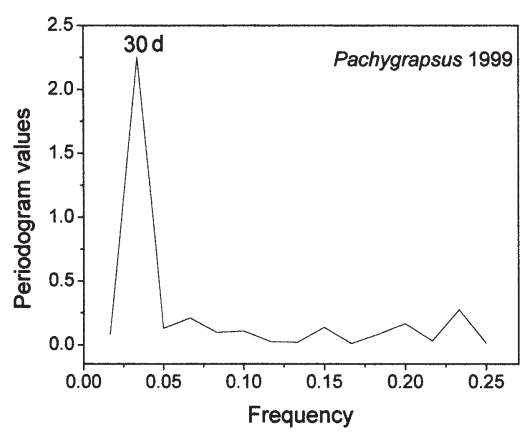

Fig. 4. Pachygrapsus marmoratus and Xantho incisus. Periodograms for each sampling period and species showing the most significant peaks within the frequency range examined

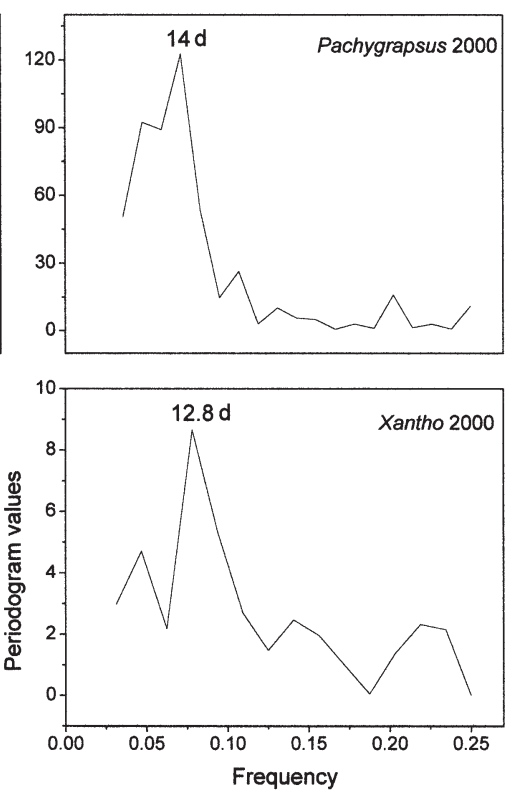


Table 4. Xantho incisus. Significance of factor interactions in log-linear models fit to time series settlement data obtained during the 2000 sampling period. Results are shown for each of the tested models, accounting for the cumulative effect of wind from 1 to 8 preceding days. The $G$-statistic, degrees of freedom and probability of type I error are shown for each case. Statistically significant values $(\mathrm{p}<0.05)$ are highlighted in bold. S: settlement rate; $\mathrm{T}$ : tide range; $\mathrm{W}$ : wind speed. ${ }^{*}$ In all cases, higher settlement rates correspond to negative or low onshore wind speed components

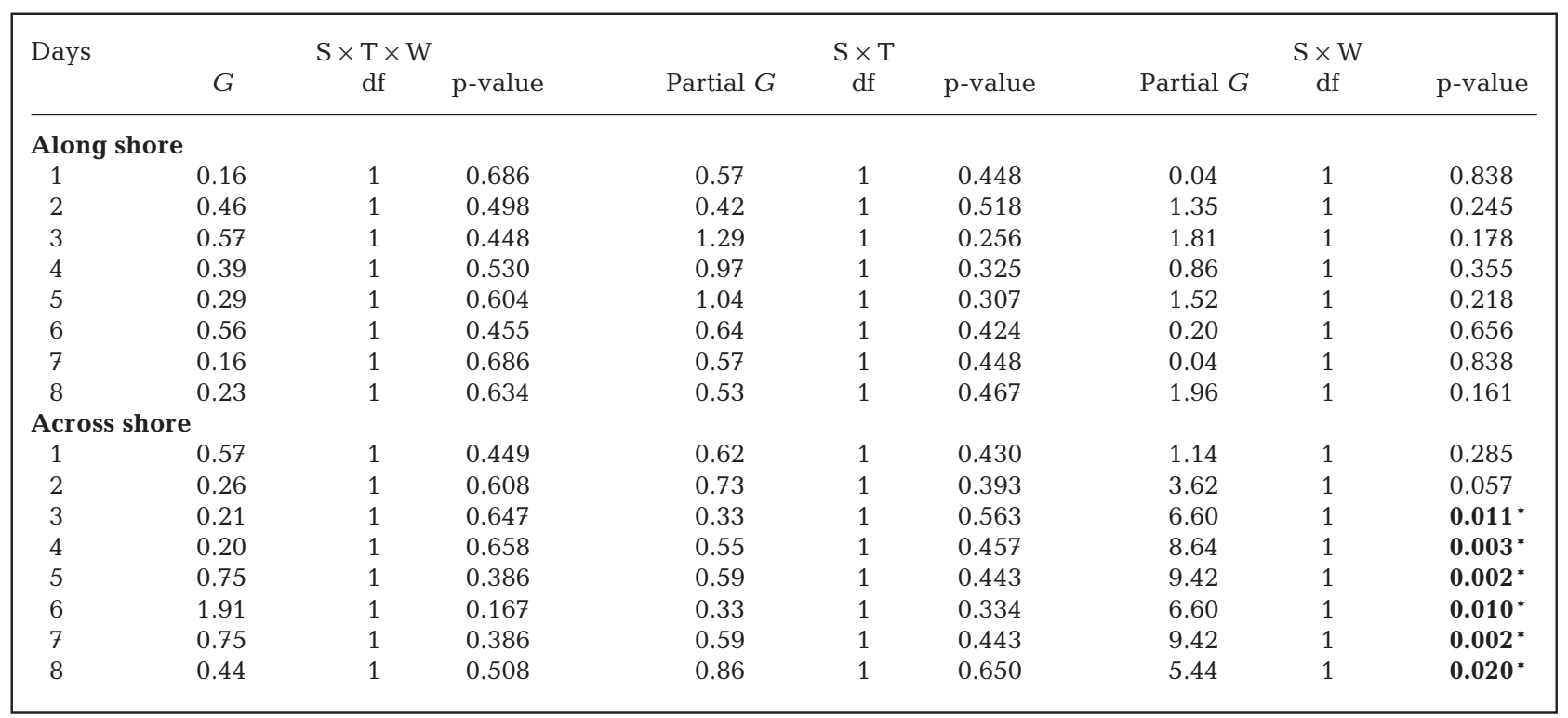

rocky coast. The cobble coverage provides adequate protection against predators since megalopae can crawl downwards to shelters inaccessible to much larger organisms. Megalopae obtained in these samples are

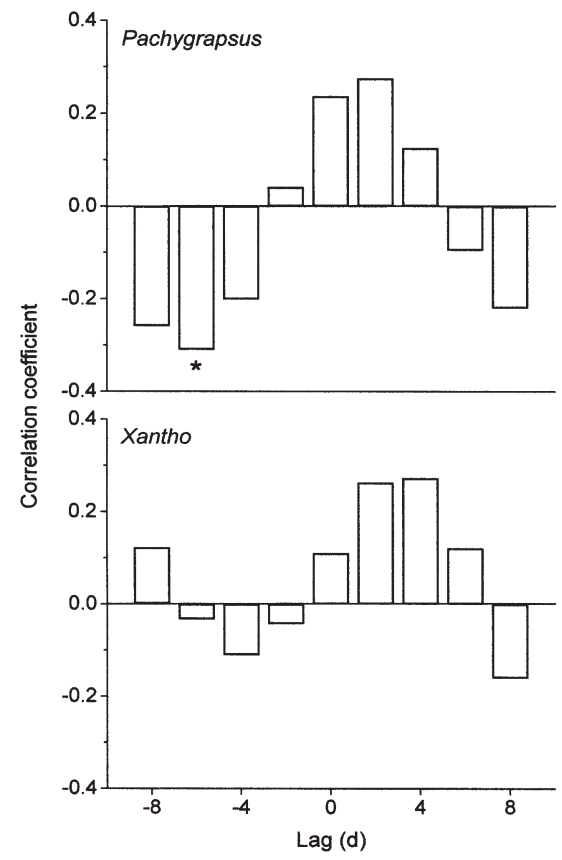

Fig. 5. Pachygrapsus marmoratus and Xantho incisus. Crosscorrelation between daily settlement rate and tide range. *Significant correlation $(\mathrm{r}=-0.31, \mathrm{p}<0.05)$ competent settlers, typically moulting to first crab stage in 1 or $2 \mathrm{~d}$ (authors' unpubl. data). Passive collectors eliciting thigmotactic response of megalopae are generally thought to select larvae ready to settle. Loose cor-

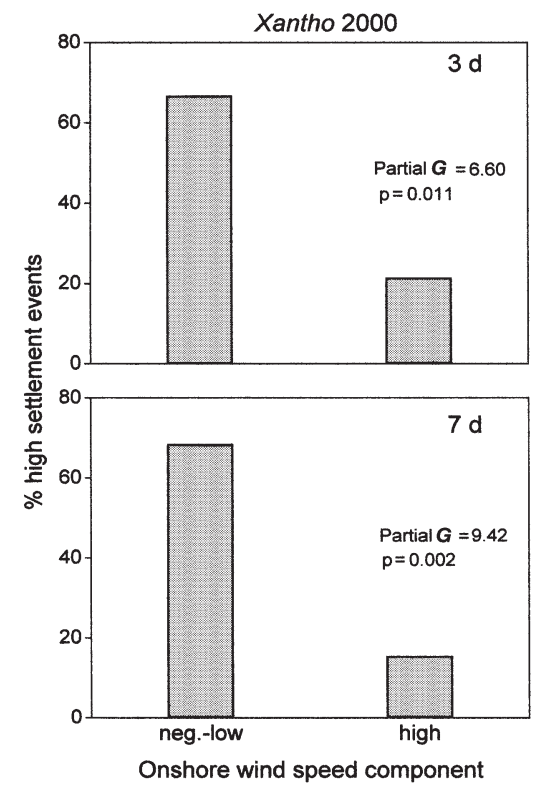

Fig. 6. Xantho incisus. Percentage of high settlement events under different across-shore wind conditions. Results of loglinear models using the wind data accounting for 3 and 7 preceding days are illustrated. Statistics shown correspond to those in Table 4 
Table 5. Pachygrapsus marmoratus. Significance of factor interactions in log-linear models fitted to time series settlement data obtained during the 1999 sampling period. See Table 4 for abbreviations. ${ }^{*}$ In both cases, high settlement rates correspond to higher onshore wind speed components

\begin{tabular}{|c|c|c|c|c|c|c|c|c|c|}
\hline \multirow[t]{2}{*}{ Days } & \multicolumn{3}{|c|}{$\mathrm{S} \times \mathrm{T} \times \mathrm{W}$} & \multicolumn{3}{|c|}{$\mathrm{S} \times \mathrm{T}$} & \multicolumn{3}{|c|}{$\mathrm{S} \times \mathrm{W}$} \\
\hline & $G$ & df & $\mathrm{p}$-value & Partial $G$ & $\mathrm{df}$ & p-value & Partial $G$ & df & $\mathrm{p}$-value \\
\hline \multicolumn{10}{|c|}{ Along shore } \\
\hline 1 & 1.55 & 2 & 0.460 & 2.11 & 2 & 0.349 & 2.37 & 2 & 0.306 \\
\hline $2^{\mathrm{a}}$ & 0.08 & 1 & 0.771 & 1.97 & 1 & 0.161 & 1.12 & 1 & 0.290 \\
\hline $3^{a}$ & 2.02 & 1 & 0.155 & 2.61 & 1 & 0.106 & 0.03 & 1 & 0.857 \\
\hline 4 & 1.62 & 2 & 0.444 & 1.79 & 2 & 0.409 & 4.71 & 2 & 0.095 \\
\hline 5 & 4.50 & 2 & 0.108 & 1.36 & 2 & 0.506 & 2.75 & 2 & 0.252 \\
\hline 6 & 1.43 & 2 & 0.488 & 1.56 & 2 & 0.458 & 4.55 & 2 & 0.130 \\
\hline 7 & 2.35 & 2 & 0.309 & 0.56 & 2 & 0.754 & 5.83 & 2 & 0.054 \\
\hline 8 & 4.42 & 2 & 0.110 & 0.61 & 2 & 0.739 & 5.17 & 2 & 0.075 \\
\hline \multicolumn{10}{|c|}{ Across shore } \\
\hline 1 & 2.14 & 2 & 0.343 & 1.60 & 2 & 0.449 & 3.24 & 2 & 0.198 \\
\hline 2 & 0.95 & 2 & 0.623 & 1.82 & 2 & 0.403 & 7.09 & 2 & $0.029^{*}$ \\
\hline 3 & 0.21 & 2 & 0.901 & 1.64 & 2 & 0.440 & 2.53 & 2 & 0.282 \\
\hline 4 & 0.43 & 2 & 0.807 & 0.99 & 2 & 0.609 & 3.00 & 2 & 0.223 \\
\hline 5 & 2.55 & 2 & 0.279 & 1.61 & 2 & 0.448 & 6.29 & 2 & $0.043^{*}$ \\
\hline 6 & 0.44 & 2 & 0.804 & 1.69 & 2 & 0.430 & 3.70 & 2 & 0.158 \\
\hline 7 & 0.73 & 2 & 0.693 & 1.41 & 2 & 0.494 & 0.44 & 2 & 0.805 \\
\hline 8 & 2.32 & 2 & 0.314 & 3.09 & 2 & 0.213 & 0.19 & 2 & 0.910 \\
\hline
\end{tabular}

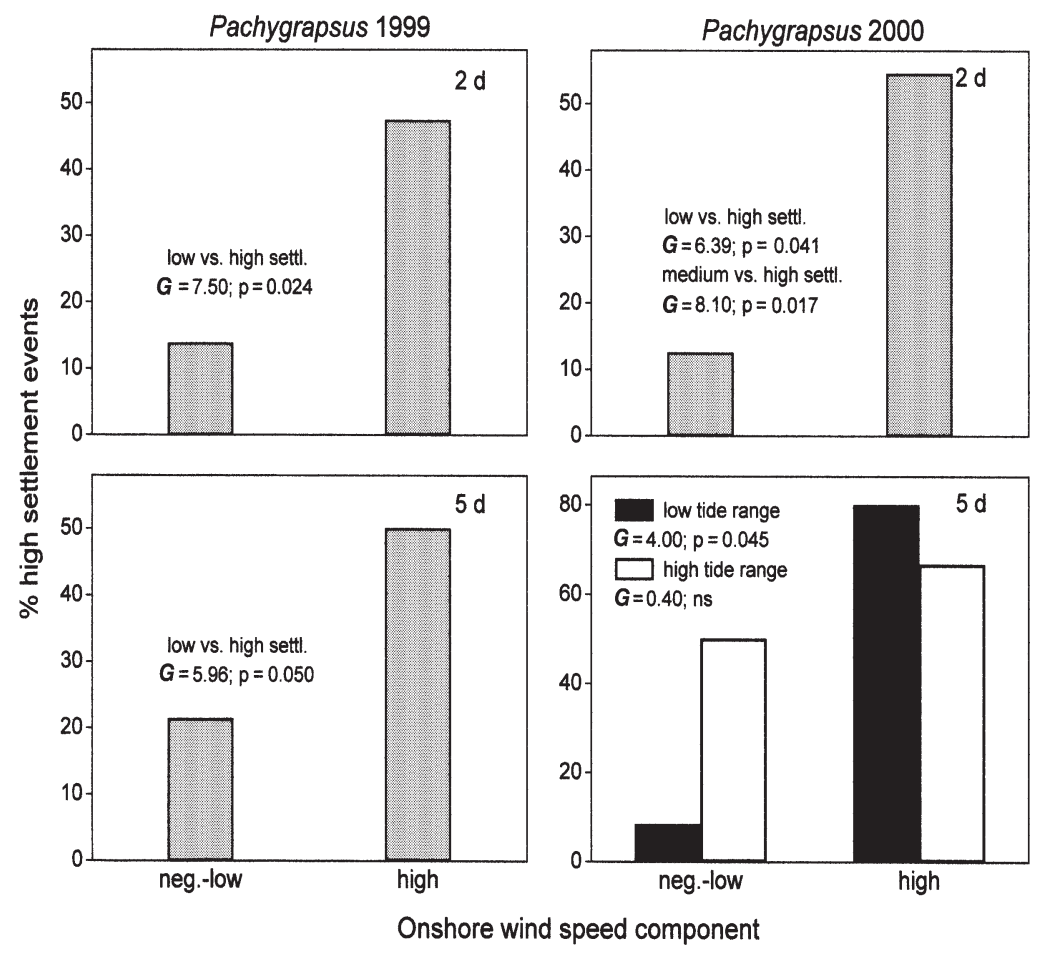

Fig. 7. Pachygrapsus marmoratus. Percentage of high settlement events under different across-shore wind conditions for the 1999 and 2000 sampling periods. Results of log-linear models using the wind data accounting for 2 and 5 preceding days are illustrated. For the 2-factor interactions shown, settlement data were split into 3 categories and statistics indicate significant results from decomposing the initial test in paired comparisons. For the 3 -factor interaction, statistics refer to independent $2 \times 2$ contingency tables relations between the number of blue crab settlers caught in hogshair collectors and the availability of megalopae in the water column apparently indicate sampling selection for competent megalopae (Goodrich et al. 1989). In contrast, the abundance of pueruli in floating 'Witham-type' surfaces indicates their concentration in the plankton but not necessarily benthic settlement (Eggleston et al. 1998). The use of natural nursery grounds to obtain density estimates of megalopae seems to be the most reliable option to measure settlement rates. However, sampling natural microhabitats where megalopae usually settle often involves undesirable destructive techniques. Manipulating cobble areas is not particularly harmful to the benthic intertidal community, but since these areas are not usually widespread along rocky shores, large eligible areas should be considered to assign an adequate number of sampling plots.

Breeding intensity does not seem to be strongly coupled to settlement rates for both lobsters (MacDonald 1986, Eggleston et al. 1998) and barnacles, in which the larval phase may take 2 to 
Table 6. Pachygrapsus marmoratus. Significance of factor interactions in log-linear models fitted to time series settlement data obtained during the 2000 sampling period. See Table 4 for abbreviations. ${ }^{*}$ In both cases, high settlement rates correspond to higher northern wind speed components

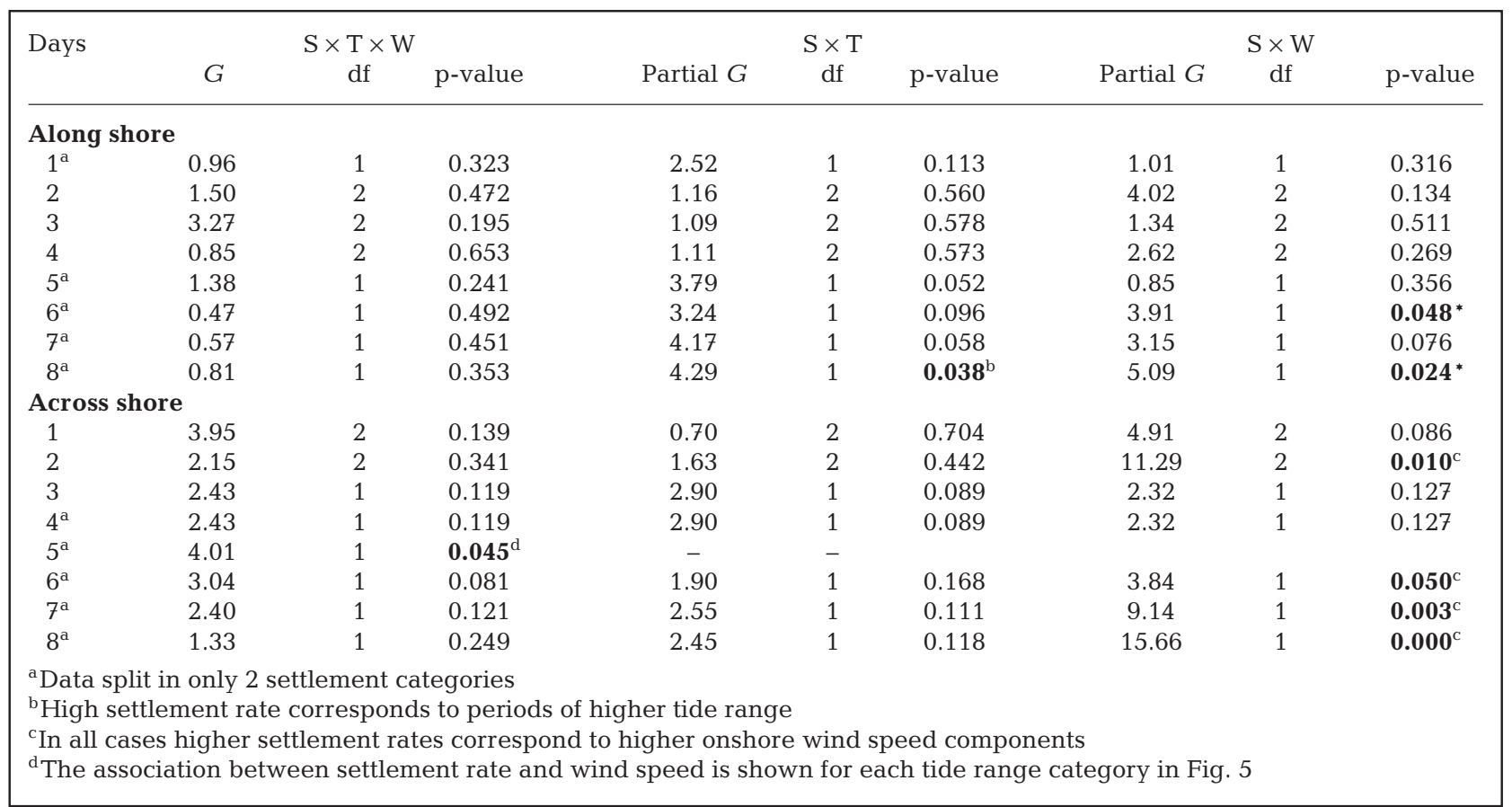

3 times longer in the plankton than in the laboratory (Farrell et al. 1991). Although the 2 are not directly related, breeding periods may constrain to some extent the settlement season of marine invertebrates. In the present study, early and late breeders roughly correspond to early and late settlers. The grapsid Pachygrapsus marmoratus and the xanthids Xantho incisus and Eriphia verrucosa are species breeding from late spring to late summer, while the portunid Necora puber and the pirimelid Pirimela denticulata breed from late winter to late spring (Zariquiey-Álvarez 1968, Ingle 1980). These species are correspondingly separated into midsummer to mid-fall and late spring to late summer settlement groups. Megalopae of Pilumnus hirtellus were, however, collected from mid-June to early August, which is unexpectedly early for a species extending breeding to September. In spite of the apparent link between breeding and settlement at the seasonal level, it is clear that a higher sampling effort is needed to better resolve the fine temporal trends of these species, especially those occurring in lower densities. While breeding periods are thought to determine to some extent the seasonal occurrence of planktonic larvae, other less predictable factors would determine settlement events in smaller temporal scales.

Considering both study periods, mesh traps were sampled from early June to early December. This time interval seems to be sufficiently long to allow compar- isons of the relative frequency of megalopae obtained for each species. All crabs known to inhabit the rocky intertidal zone in the study region (Flores \& Paula 2001) were detected in the samples. Yet overall species rankings differed considerably between the adult and megalopal account. The predominance of Pachygrapsus marmoratus is noteworthy in both life phases. However, the relative frequency of Xantho incisus and Pirimela denticulata megalopae is higher than expected. This is not surprising since visual counts tend to underestimate the abundance of adults, which predominate under boulder and cobble areas ( $X$. incisus) or remain buried in moisten sandy patches ( $P$. denticulata). Otherwise, Eriphia verrucosa was found to be the second most abundant species in adult surveys but their megalopae were markedly scarce in mesh traps. Some possible reasons may be advanced to explain this finding. For instance, larvae may have been actively selecting other preferred substrata (e.g. Keough \& Downes 1982, Gebauer et al. 1998, Stevens \& Kittaka 1998, Strasser \& Felder 1999) or advected to other areas far from the parental stocks (e.g. McConnaughey et al. 1992, Queiroga 1995). Present results do not allow interpretation of the lack of E. verrucosa megalopae in any detail.

Spatial scales at which a given variable shows significant trends may indicate potential processes affecting that variable (Underwood \& Chapman 1996). Settle- 
ment variability at small spatial scales from a few centimetres to several tens of metres may be attributable to substrate selection, while variability at larger scales is likely to reflect hydrologically driven heterogeneity. The latter mechanisms appear to be operating at different spatial scales in turn. Patchiness at a scale of 1 to $2 \mathrm{~km}$ is typical of neustonic cancrid megalopae, probably reflecting complex local hydrographic conditions (Clancy \& Cobb 1997). Similar aggregation patterns are expected to take place in planktonic organisms retained in the upper water layers. At settlement, larvae transported in surface slicks associated with internal waves are delivered irregularly along the coastline (Shanks \& Wright 1987), causing significant spatial variability at the scale of several hundred of metres, similar to what may be expected from aggregations of plankton promoted by complex, near-shore, smallscale currents (Alldredge \& Hamner 1980). Settlement of the common shore crab Pachygrapsus marmoratus varied between sampled areas separated by several hundred metres but not within smaller-scale distances. This result indicates that hydrological features operating in coastal areas are the main factors affecting the settlement distribution of this grapsid crab within the spatial range examined herein. Variability among sites located from 10 to some hundreds of kilometres apart responds to mesoscale oceanographic processes. Wing et al. (1995a) found that settlement of brachyuran and porcelain crabs follows relaxation events of northerly upwelling-favourable winds along the coast of California, USA. These authors verified an along-shore settlement gradient and hypothesised that distance from a southern propagule source may be the major reason for the observed pattern. Such large-scale spatial traits are found to be stable through time (Johnson et al. 1986, Eggleston et al. 1998). Smaller-scale variability should probably also be temporally coherent, since it largely results from the same transport processes prevailing at a given coastline. It is interesting to note that present results on the spatial distribution of megalopae indicate opposed trends between the truly intertidal $P$. marmoratus and the low intertidal to subtidal crabs Xantho incisus, Necora puber and Pirimela denticulata. Those species are likely to be transported ashore by different means.

Palma et al. (1999) performed an analogous hierarchical ANOVA to test for spatial scales of settlement variability in the rock crab Cancer irroratus and the American lobster Homarus americanus, controlling for depth $(10 \mathrm{~m})$ and substratum (cobble). They found interesting results indicating no differences at any scale for the lobster and only inter-regional variability (hundreds of kilometres) for the rock crab. This may indicate that, disregarding microhabitat selection, those subtidal settlers may gradually join the benthic population as competency is achieved with no major effect of smaller-scale hydrological features. Settling in the rocky intertidal zone is apparently a strikingly different process. Coastal hydrological characteristics are apparently determining the distribution of competent megalopae, which would be finally swept into the intertidal zone according to wave action. Under these conditions, settlers are not likely to systematically probe the substratum and resume swimming but rather find adequate refuge once they reach the shore. Settlement success naturally depends on the proximity of adequate shelter, so that recent recruits are usually found in particularly complex habitats (e.g. Hines 1982, Navarrete \& Castilla 1990, Heck \& Hambrook 1991, Spivak et al. 1994, Flores \& Negreiros-Fransozo 1999) accounting for small-scale spatial patchiness when the 'microhabitat' factor is not considered (Palma et al. 1999, Robinson \& Tully 2000).

Interannual settlement variability is usually high in brachyuran populations. For estuarine crab species along the eastern coast of the USA, yearly variation is usually around a factor of 3 to 5 (van Montfrans et al. 1990, Boylan \& Wenner 1993), but it may be much higher, up to 13 times in consecutive years (Rabalais et al. 1995). Similar fluctuation was observed for spiny lobsters, with a multiplicative factor ranging from 3.3 to 6.5 (Phillips 1972, Marx 1986, Briones-Fourzán 1994). The present results indicate that the input of new settlers to intertidal crab populations may be even more variable, since interannual post-larval supply rendered 9- to 14-fold differences for the most common species, Pachygrapsus marmoratus and Xantho incisus. Factors affecting dispersal and later onshore migration are predicted to contribute soundly to this variable pattern. In this study we attempted to provide some insight on the potential mechanisms responsible for promoting brachyuran settlement in the rocky intertidal zone.

The magnitude of the across-shore wind component was identified to be the most important variable explaining the abundance of settlers for both Pachygrapsus marmoratus and Xantho incisus. Interestingly, a given across-shore wind event produces antagonistic effects in these species. While onshore wind forcing favours settlement in $P$. marmoratus, it is its relaxation or opposed offshore stress that is presumably bringing to shore the megalopae of $X$. incisus. These results do not support eventual cross-shelf transport expected from well-known mesoscale hydrological processes. Along the Portuguese coast, near-surface wind is basically controlled by the Azores High, which migrates northwards between March and August and determines the seasonal directional shift of westerly moderate winter winds to stronger winds during the summer blowing from the north or north-west. Northerly up- 
welling-favourable winds dominate from June to October and induce Ekman seaward transport of the surface layer and coastal upwelling of cold water brought from 60 to $120 \mathrm{~m}$ depths (Fiúza 1982). During the upwelling season, continuous cross-shelf flow is only clear during relaxation events (Jorge da Silva 1992), when onshore larval transport may occur, as suggested by Queiroga (2000) for the megalopae of Carcinus maenas over the continental shelf off northern Portugal. If this mechanism is responsible for onshore advection of the species considered in the present study, then a significant effect of the along-shore wind component would be expected to emerge in the tested models. Settlement of megalopae would be favoured by a decreasing intensity of upwelling-favourable northerly winds and subsequent forcing of southern wind components, similar to what has been reported for barnacles (Farrell et al. 1991) and subtidal decapod crustaceans (Wing et al. 1995a,b) along the coast of California. However, the effect of along-shore wind components is regarded in the present study as inconsistent at best.

Significant interactions of along-shore wind speed components, pointing to an association between north winds and high settlement rate, were only found during the 2000 season for Pachygrapsus marmoratus and considered to be reflecting the stress effect of winds blowing from the north-west, which prevailed during this period and are equally represented in the across-shore axis. Otherwise, across-shore wind speed components are consistently related to settlement rate during both sampling periods in this grapsid and during the single examined season for Xantho incisus. Megalopae of P. marmoratus are large and active swimmers, resembling those of the congener Pachygrapsus crassipes (Shanks 1983, 1995a). We observed on a number of occasions small groups of $P$. marmoratus megalopae swimming just below the surface; it is assumed that these larvae are mostly neustonic, as already reported for $P$. crassipes. Within the neuston layer, downwind drift takes place over Langmuir circulation cells even under the influence of strong winds (Hamner \& Schneider 1986), which are commonly observed in our study area. In this nearsurface position, flow deflection due to the Ekman effect is much restricted, usually not higher than 10 to $15^{\circ}$ (Huang 1979, Bakun 1996). Both wind drift currents and Langmuir circulation are therefore plausible mechanisms of onshore transport of $P$. marmoratus megalopae. While onshore wind stress causes nearshore downwelling, thus transporting their megalopae to the coast, the net bottom flow is offshore, compensating for the coastal rise of sea level. Under conditions of offshore wind forcing, the inverted process takes place, i.e. the sea level drops and a subsurface shoreward water flow causes upwelling of deeper water (Shanks 1995b). Shanks (1998) showed these upwelling and downwelling compensating coastal flows at a near-shore site in North Carolina, USA, by cross-correlating across- and along-shore wind stress records to current speed and direction at both the surface and near bottom. If these flow dynamics apply to our coastal area, then larvae placed at different heights within the water column may be transported in opposite directions.

Further research to specifically test this model should first address the vertical distribution of megalopae. While there are acceptable grounds to assume the neustonic habit of Pachygrapsus marmoratus, no direct clues are available to speculate on the vertical distribution of Xantho incisus. Thorough surveys of the 3-dimensional spatial distribution of brachyuran megalopae are too scarce. Abelló \& Guerao (1999) carried out an extensive sampling program and delimited the megalopal distribution of many species off the Catalan coast, northwestern Mediterranean. Unfortunately, that study was conducted in spring when megalopae of both $X$. incisus and P. marmoratus are still absent from the plankton. Yatsuzuka \& Quintana (1985) obtained plankton samples at different depths from which megalopae of 42 taxa were identified. Xanthids and grapsids were predominant, but the authors did not provide any information on their vertical distribution. The only relevant account, although rather marginal, was given by Olivar et al. (1998), who mention that the megalopae of a group of species, including $X$. incisus, were mainly found in the uppermost surface layer. Yet it should be noted that $X$. incisus is a species still common at depths of 30 to $40 \mathrm{~m}$ over the inner shelf (Ingle 1980, Falciai \& Minervini 1995). Megalopae reaching the intertidal zone may well be brought ashore while already distributed close to benthic subtidal populations, thus in a significantly deeper layer. The same scenario may be conceivable for other species showing similar vertical distribution of adults such as Necora puber and Pirimela denticulata.

Tidally driven mechanisms are regarded as secondary factors promoting cross-shelf transport but they are also likely to occur, at least in the case of Pachygrapsus marmoratus, in which spectral analyses revealed a clear semilunar period during the 2000 season. The apparent lunar cycle during the 1999 sampling period may be due to low densities of megalopae, below detectable ranges during weaker settlement events. Fortnightly periodicity is further supported by a cross-correlation analysis, suggesting synchronous variation tied to tidal range, and significant terms of log-linear models. Although usually masked by the more pronounced effect of across-shore wind speed, a significant 'settlement rate' versus 'tide range' interac- 
tion (Table 6) also indicates that higher settlement rates are more common during periods of high tidal amplitude. Semilunar periodicity is expected if transport in the convergence zone of tidally forced internal waves is significant, as observed in P. crassipes megalopae (Shanks 1983), galatheids (Zeldis \& Jillet 1982) and fishes (Kingsford \& Choat 1986). Onshore propagating non-linear trains of internal waves were observed using radar images off the northern Portuguese coast. These sets are probably generated at the continental shelf break by the interaction of the tidal current with underwater bottom topography (Alpers 1985). However, if internal waves were transporting these megalopae shoreward, one would expect to find lagged cross-correlations between settlement rate and tide range, which was not the case. Depending on the propagation velocity of internal waves and the continental shelf width, settlement maxima could coincide with higher tidal ranges, but this is not the most probable outcome. Alternatively, it can be suggested that megalopae are more abundant during periods of higher intertidal range simply because the water flux above the settling area is also higher at that times. A 3-factor interaction involving both 'tide range' and 'across-shore wind speed' (Table 6, Fig. 7) suggests that the effect of onshore transport by means of wind forcing is more limited under conditions of high tide range, when megalopae are likely to be already present in high densities. This interaction is probably more relevant than indicated in the tested models due to constraints of statistical power.

Compared with most temporal patterns documented for brachyurans, settlement events in these shore species, particularly Pachygrapsus marmoratus, are less episodic, usually protracted over several days. During both study periods, but especially from August to midSeptember 2000, settlement-favourable winds are also consistent over a relatively long period. Larvae are presumably concentrated in coastal areas during these events and gradually washed ashore under the influence of tides. Settlement rates for P. marmoratus seem to be higher around the new moon than full moon but proper statistical comparisons are not possible due to the low number of settlement events. Higher settlement during the new moon was repeatedly observed in spiny lobsters (e.g. Phillips 1972, MacDonald 1986). Some authors have suggested that settling during this lunar phase would reduce susceptibility to visual predators (Acosta et al. 1997, Eggleston et al. 1998). Future investigations on fine temporal settlement patterns of brachyurans from intertidal rocky shores should address this hypothesis by both comparing diurnal and nocturnal density of megalopae and examining longer time series to enable robust statistical testing.
Acknowledgements. This work was supported by the 'Fundação para a Ciência e a Tecnologia', which granted a PhD fellowship to A.A.V.F. We are grateful to Henrique Queiroga for indicating useful literature and providing valuable comments on some topics discussed in this paper. We also thank Pere Abelló for his help while searching updated information on larval distribution and Maria Dornelas for fruitful discussion. Finally, we are indebted to Cátia Bartiloitti, Olga Santos, João Gago and Carla Micheletti Flores for their assistance during fieldwork.

\section{LITERATURE CITED}

Abelló P, Guerao G (1999) Temporal variability in the vertical and mesoscale spatial distribution of crab megalopae (Crustacea: Decapoda) in the northwestern Mediterranean. Estuar Coast Shelf Sci 49:129-139

Acosta CA, Matthews TR, Butler MJ IV (1997) Temporal patterns and transport processes in recruitment of spiny lobster (Panulirus argus) postlarvae to south Florida. Mar Biol 129:79-85

Alldredge AL, Hamner WM (1980) Recurring aggregation of zooplankton by a tidal current. Estuar Coast Shelf Sci 10: 31-37

Alpers W (1985) Theory of radar imaging of internal waves. Nature 314:245-247

Bakun A (1996) Patterns in the ocean. Ocean processes and marine population dynamics. California Sea Grant College system - National Oceanic and Atmospheric Administration and Centro de Investigaciones Biológicas del Noroeste, La Paz

Bishop YMM, Fienberg SE, Holland PW (1975) Discrete multivariate analysis: theory and practice. MIT Press, Cambridge

Boylan JM, Wenner EL (1993) Settlement of brachyuran megalopae in a South Carolina, USA, estuary. Mar Ecol Prog Ser 97:237-246

Briones-Fourzán P (1994) Variability in postlarval recruitment of the spiny lobster Panulirus argus (Latreille, 1804) to the Mexican Caribbean coast. Crustaceana 66:326-340

Broekhuysen GJ (1941) The life history of Cyclograpsus punctatus: breeding and growth. Trans R Soc S Afr 28:331-366

Clancy M, Cobb JS (1997) Effect of wind and tidal advection on distribution patterns of rock Cancer irroratus megalopae in Black island Sound, Rhode Island. Mar Ecol Prog Ser 132:217-225

Eggleston DB, Lipcius RN, Marshall LS Jr, Ratchford SG (1998) Spatiotemporal variation in postlarval recruitment of the Caribbean spiny lobster in the Central Bahamas: lunar and seasonal periodicity, spatial coherence and wind forcing. Mar Ecol Prog Ser 174:22-49

Falciai L, Minervini M (1995) Guía de los crustáceos decápodos de Europa. Ediciones omega, S.A. Barcelona, Lisbon

Farrell TM, Bracher D, Roughgarden J (1991) Cross-shelf transport causes recruitment to intertidal populations in central California. Limnol Oceanogr 36:279-288

Fiúza AFG (1982) The Portuguese coastal upwelling system. In: Actual problems of oceanography in Portugal. JNICT/ NATO Marine Sciences Panel, Lisbon, p 45-71

Flores AAV, Negreiros-Fransozo ML (1998) Factors determining seasonal breeding in a subtropical population of the shore crab Pachygrapsus transversus (Gibbes, 1850) (Brachyura, Grapsidae). Invertebr Reprod Dev 34:149-155

Flores AAV, Negreiros-Fransozo ML (1999) On the population biology of the mottled shore crab Pachygrapsus transver- 
sus (Gibbes, 1850) (Brachyura, Grapsidae) in a subtropical area. Bull Mar Sci 65:59-73

Flores AAV, Paula J (2000) Larval and early juvenile stages of Pirimela denticulata (Montagu, 1808) (Crustacea, Brachyura, Pirimelidae) obtained in the laboratory. J Nat Hist 34: 2123-2143

Flores AAV, Paula J (2001) Species composition and intertidal distribution of brachyuran crabs at two rocky shores in Central Portugal. In: Paula J, Flores AAV, Fransen C (eds) Advances in decapod crustacean research. Proc 7th Colloq Crustacea Decapoda Mediterranea. Developments in hydrobiology 154. Kluwer Publishers, Dordrecht, p 171-177

Fukui Y (1988) Comparative studies on the life history of the grapsid crabs (Crustacea, Brachyura) inhabiting intertidal cobble and boulder shores. Publ Seto Mar Biol Lab 33: 121-162

Fukui Y (1990) Breeding and moulting cycles of Gaetice depressus (De Haan) (Brachyura: Grapsidae) under laboratory conditions. Res Crustac 19:83-90

Gaines S, Roughgarden J (1985) Larval settlement rate: a leading determinant of structure in an ecological community of the marine intertidal zone. Proc Natl Acad Sci USA 82:3707-3711

Gebauer P, Walter I, Anger K (1998) Effects of substratum and conspecific adults on the metamorphosis of Chasmagnathus granulata (Dana) (Decapoda: Grapsidae) megalopae. J Exp Mar Biol Ecol 223:185-198

Goodrich DM, van Montfrans J, Orth RJ (1989) Blue crab megalopal influx to Chesapeake Bay: evidence for a winddriven mechanism. Estuar Coast Shelf Sci 29:247-260

Guerao G, Abelló P, Cuesta JA (1997) Morphology of the megalopa and first crab of the mediolittoral crab Pachygrapsus marmoratus (Brachyura, Grapsidae, Grapsinae). Zoosystema 19:439-449

Hamner WM, Schneider D (1986) Regularly spaced rows of medusae in the Bering Sea: role of Langmuir circulation. Limnol Oceanogr 31:171-177

Heck KL, Hambrook JA (1991) Intraspecific interactions and risk of predation for Dysopanopeus sayi (Decapoda, Xanthidae) living on polychaete (Filograna implexa, Serpulidae) colonies. Mar Ecol Prog Ser 12:243-250

Hines AH (1982) Coexistence in a kelp forest: size, population dynamics, and resource partitioning in a guild of spider crabs (Brachyura, Majidae). Ecol Monogr 52:179-198

Huang NE (1979) On surface drift currents in the ocean. J Fluid Mech 91:191-208

Ingle RW (1980) British crabs. British Museum (Natural History), Oxford University Press, London

Ingle RW (1991) Larval stages of northeastern atlantic crabs, an illustrated key. Chapman and Hall, Natural History Museum Publications, London

Johnson DF, Hess KW (1990) Numerical simulations of blue crab larval dispersal and recruitment. Bull Mar Sci 46:195-213

Johnson DF, Bostford LW, Methot RD Jr, Wainwright TC (1986) Wind stress and cycles in Dungeness crab (Cancer magister) catch off California, Oregon, and Washington. Can J Fish Aquat Sci 43:838-845

Johnson DR, Hester BS (1989) Larval transport and its association with recruitment of blue crabs to Chesapeake Bay. Estuar Coast Shelf Sci 28:459-472

Jones MB, Epifanio CE (1995) Settlement of brachyuran megalopae in Delaware Bay: an analysis of time series data. Mar Ecol Prog Ser 125:67-76

Jorge da Silva A (1992) Dependence of upwelling related circulation on wind forcing and stratification over the Portuguese northern shelf. ICES Counc Meet Pap C 17:1-12
Keough MJ, Downes BJ (1982) Recruitment of marine invertebrates: the role of active larval choices and early mortality. Oecologia 54:348-352

Kingsford MJ, Choat JH (1986) Influence of surface slicks on the distribution and onshore movements of small fish. Mar Biol 91:161-171

Knudsen JW (1960) Reproduction, life history and larval ecology of the California Xanthidae, the pebble crabs. Pac Sci 14:3-17

Lumare F, Gozzo S (1972) Sviluppo larvale del crostaceo Xantideae Eriphia verrucosa (Forskål, 1775) in condizioni di laboratorio. Boll Pesca Piscic Idrobiol 27:185-209

MacDonald CD (1986) Recruitment of the puerulus of the spiny lobster, Panulirus marginatus, in the Hawaii. Can J Fish Aquat Sci 43:2118-2125

Marx JM (1986) Settlement of spiny lobster, Panulirus argus, pueruli in south Florida: an evaluation from two perspectives. Can J Fish Aquat Sci 43:2221-2227

McConnaughey RA, Armstrong DA, Hickey BM, Gunderson DR (1992) Juvenile dungeness crab (Cancer magister) recruitment variability and oceanic transport during the pelagic larval phase. Can J Fish Aquat Sci 49:2028-2044

McDonald J (1982) Divergent life history patterns in the cooccurring intertidal crabs Panopeus herbstii and Eurypanopeus depressus (Crustacea: Brachyura: Xanthidae). Mar Ecol Prog Ser 8:173-180

Mense DJ, Posey MH, West T, Kincheloe K (1995) Settlement of brachyuran postlarvae along the North Carolina coast. Bull Mar Sci 57:793-806

Metcalf KS, van Montfrans J, Lipcius RN, Orth RJ (1995) Settlement indices for blue crab megalopae in the York River, Virginia: temporal relationships and statistical efficiency. Bull Mar Sci 57:781-792

Navarrete AS, Castilla JC (1990) Resource partitioning between intertidal predatory crabs: interference and refuge utilization. J Exp Mar Biol Ecol 143:101-129

O'Connor NJ (1993) Settlement and recruitment of the fiddler crabs Uca pugnax and U. pugilator in a North Carolina, USA, salt marsh. Mar Ecol Prog Ser 93:227-234

Olivar MP, Sabates A, Abello P, Garcia M (1998) Transitory hydrographic structures and distribution of fish larvae and neustonic crustaceans in the north-western Mediterranean. Oceanol Acta 21:95-104

Oliveira E, Masunari S, Sicuro AHG (1995) Uma armadilha para captura de Porcellanidae (Crustacea, Decapoda) do mediolitoral de praias rochosas. Rev Bras Zool 12:343-353

Palma AT, Steneck RS, Wilson CJ (1999) Settlement-driven, multiscale demographic patterns of large benthic decapods in the Gulf of Maine. J Exp Mar Biol Ecol 241: $107-136$

Paula J, Dray T, Queiroga H (2001) Interaction of offshore and inshore processes controlling settlement of brachyuran megalopas at Saco mangrove creek, Inhaca Island (South Mozambique). Mar Ecol Prog Ser 215:251-260

Phillips BF (1972) A semi-quantitative collector of the puerulus larvae of the western rock lobster Panulirus cygnus George (Decapoda, Palinuridae). Crustaceana 22:147-154

Phillips BF (1986) Prediction of commercial catches of the western rock lobster Panulirus cygnus. Can J Fish Aquat Sci 43:2126-2130

Queiroga H (1995) Processos de dispersão e recrutamento das larvas do caranguejo Carcinus maenas (L.) na Ria de Aveiro. PhD thesis, Universidade de Aveiro

Queiroga H (2000) Distribution and drift of the crab Carcinus maenas (L.) (Decapoda, Portunidae) larvae over the continental shelf off northern Portugal in April 1991. J Plankton Res 18:1981-2000 
Rabalais NN, Burditt FR Jr, Coen LD, Cole BE, Eleuterius C, Heck KL Jr, McTigue TM, Morgan SG, Perry HM, Truesdale FM, Zimmer-Faust RK, Zimmerman RJ (1995) Settlement of Callinectes sapidus megalopae on artificial collectors in four Gulf of Mexico estuaries. Bull Mar Sci 57: $855-876$

Rayner JN (1971) An introduction to spectral analysis. Pion Limited, London

Reyns N, Sponaugle S (1999) Patterns and processes of brachyuran crab settlement to Caribbean coral reefs. Mar Ecol Prog Ser 185:155-170

Rice AL, Ingle RW (1975) The larval development of Carcinus maenas (L.) and C. mediterraneus Czerniavsky (Crustacea, Brachyura, Portunidae) reared in the laboratory, Bull Br Mus (Nat Hist) Zool 28:101-119

Robinson M, Tully O (2000) Spatial variability in decapod community structure and recruitment in sub-tidal habitats. Mar Ecol Prog Ser 194:133-141

Rohlf FJ, Sokal RR (1981) Statistical tables, 2nd edn. WH Freeman and Company, New York

Roughgarden J, Gaines S, Possingham H (1988) Recruitment dynamics in complex life cycles. Science 241:1460-1466

Shanks AL (1983) Surface slicks associated with tidal forced internal waves may transport pelagic larvae of benthic invertebrates and fishes shoreward. Mar Ecol Prog Ser 13: 311-315

Shanks AL (1985) Behavioral basis of internal-wave-induced shoreward transport of megalopae of the crab Pachygrapsus crassipes. Mar Ecol Prog Ser 24:289-295

Shanks AL (1995a) Orientated swimming by megalopae of several eastern North Pacific crab species and its potential role in their onshore migration. J Exp Mar Biol Ecol 186: $1-16$

Shanks AL (1995b) Mechanisms of cross-shelf dispersal of larval invertebrates and fish. In: McEdward L (ed) Ecology of marine larvae. CRC Press, Boca Raton, p 323-367

Shanks AL (1998) Abundance of post-larval Callinectes sapidus, Penaeus spp., Uca spp., and Libinia spp. collected at an outer coastal site and their cross-shelf transport. Mar Ecol Prog Ser 168:57-69

Shanks AL, Wright WG (1987) Internal-wave-mediated shoreward transport of cyprids, megalopae, and gammarids and correlated longshore differences in the settling rate of intertidal barnacles. J Exp Mar Biol Ecol 114:1-13

Sokal R, Rohlf FJ (1995) Biometry: the principles and practice of statistics in biological research, 3rd edn. WH Freeman and Company, New York

Spivak E, Anger K, Luppi T, Bas C, Ismael D (1994) Distribution and habitat preferences of two grapsid crab species in Mar Chiquita Lagoon (Province of Buenos Aires, Argentina). Helgol Wiss Meeresunters 48:59-78

Editorial responsibility: Otto Kinne (Editor),

Oldendorf/Luhe, Germany
Stevens BG, Kittaka J (1998) Postlarval settling behavior, substrate preference and time to metamorphosis for red king crab Paralithodes camtschaticus. Mar Ecol Prog Ser 167: 197-206

Strasser KM, Felder DL (1999) Sand as stimulus for settlement in the ghost shrimp Callichirus major (say) and C. islagrande (Schmitt) (Crustacea: Decapoda: Thalassinidea). J Exp Mar Biol Ecol 239:211-222

Swartz RC (1976) Sex ratio as a function of size in the xanthid crab, Neopanope sayi. Am Nat 110:898-900

Tsuchida S, Watanabe S (1997) Growth and reproduction of the grapsid crab Plagusia dentipes (Decapoda, Brachyura). J Crustac Biol 17:90-97

Underwood AJ (1997) Experiments in ecology. Their logical design and interpretation using analysis of variance. Cambridge University Press, Cambridge

Underwood AJ, Chapman MG (1996) Scales of spatial patterns of distribution of intertidal invertebrates. Oecologia 107:212-224

van Montfrans JC, Peery A, Orth RJ (1990) Daily, monthly and annual settlement patterns by Callinectes sapidus and Neopanope sayi megalopae on artificial collectors deployed in the York River, Virginia: 1985-1988. Bull Mar Sci 46:214-229

Vannini M, Gherardi F (1988) Studies on the pebble crab Eriphia smithi MacLeay 1838 (Xanthoidea, Menippidae): patterns of relative growth and population structure. Trop Zool 1:203-216

Wahle RA, Incze LS (1997) Pre- and post-settlement processes in recruitment of the American lobster. J Exp Mar Biol Ecol 217:179-207

Williams DA (1976) Improved likelihood ratio tests for complete contingency tables. Biometrika 63:33-37

Wing SR, Bostford LW, Largier JL, Morgan LE (1995a) Spatial structure of relaxation events and crab settlement in the northern California upwelling system. Mar Ecol Prog Ser 128:199-211

Wing SR, Largier JL, Bostford LW, Quinn JF (1995b) Settlement and transport of benthic invertebrates in an intermittent upwelling region. Limnol Oceanogr 40:316-329

Yatsuzuka K, Quintana R (1985) Ecological studies on the planktonic brachyuran megalopa in the coast of Tosa Bay. Rep USA Mar Biol Inst Kochi Univ 7:87-109

Yau PM (1992) Breeding and seasonal population changes of Gaetice depressus (Decapoda : Grapsidae) on Hong Kong shores. Asian Mar Biol 9:181-192

Zariquiey-Álvarez R (1968) Crustáceos Decápodos Ibéricos. Invest Pesq 32:1-510

Zeldis JR, Jillet JB (1982) Aggregation of pelagic Munida gregaria (Fabricius) (Decapoda, Anomura) by coastal fronts and internal waves. J Plankton Res 4:839-845

Submitted: April 23, 2001; Accepted: September 20, 2001

Proofs received from author(s): March 5, 2002 